\title{
POTENTIAL OF WATER EXTRACT OF THE WHITE FRANGIPANI (Plumeria acuminate) and HIBISCUS (Hibiscus tiliaceus) LEAVES POWDER AS TEXTILE NATURAL DYES
}

\author{
Sri Mulyani ${ }^{1,2 *}$, Kris Siska Aristia', Ardhia Putri Sabrina', Afifatul Arfiah', and Badrun Niam ${ }^{1}$ \\ ${ }^{1}$ Chemistry Education Study Program, Universitas Sebelas Maret \\ Jl. Ir. Sutami No 36 A, Surakarta 57126, Central Java, Indonesia \\ ${ }^{2}$ Center of Biotechnology and Biodiversity, Research and Development, Universitas Sebelas Maret \\ Jl. Ir. Sutami 36 A, Surakarta 57126, Central Java, Indonesia \\ *Correspondence: email: srimulyaniuns@staff.uns.ac.id
}

Received: Dec 04, 2019

Accepted: April 29, 2020

Online Published: April 30, 2020

DOI : 10.20961/jkpk.v5i1. 25810

\begin{abstract}
Synthetic dyes have a high environmental impact, especially on waters. The use of natural dyes for textiles provides new hope for ecological improvement. This article is to find out the yield of water extract of white frangipani (Plumeria acuminate) and hibiscus (Hibiscus tiliaceus) leaves-powder, as well as to find out whether the water extracts have potential as textile natural dyes. Natural dyes must have a good quality of fastness. For this reason, the color fastness tests for washing with a launder meter and colorfastness against rubbing with a crock meter are performed. Colorfastness is assessed by comparing color changes to washing with grayscale and color changes due to staining on fabric with staining scale. The rubbing test is carried out on the wet and dry cloth. Cotton and polyester fabrics are samples that will be colored. Fixers used to bind dyes are $\mathrm{Al}_{2}\left(\mathrm{SO}_{4}\right)_{3}$, $\mathrm{CaCO}_{3}$, and $\mathrm{FeSO}_{4} \cdot \mathrm{H}_{2} \mathrm{O}$. The results show that the water extraction of hibiscus and white frangipani leaves powder gave a yield of $11 \%(\mathrm{w} / \mathrm{w})$ and $27 \%(\mathrm{w} / \mathrm{w})$, respectively. The test of colorfastness against washing showed that both water extract of the white frangipani dan hibiscus leaves has a pretty good average quality in staining scale but less in grayscale. The test against rubbing shows that the type of fixer used affects the quality of the colorfastness, but in general, the water extract of white frangipani leaves gives better quality as a potential of natural dye than hibiscus leaves.
\end{abstract}

Keywords: extraction, white frangipani leaf, hibiscus leaf, natural dye, textile

\section{INTRODUCTION}

The need for clothing is getting higher, and this has resulted in the need for textile dyes also increasing. Textile dyes commonly used in fabric coloring are dyes derived from synthetic dyes [1]. Clothing manufacturers widely use synthetic dyes because they have low prices, there are a variety of color variations, good quality, and easy to obtain, but excessive use of synthetic dyes have caused many environmental problems, where most synthetic dyes contain pollutants dangerous heavy metals. Heavy metals that are usually found in synthetic dyes include metals $\mathrm{Cu}, \mathrm{Ni}, \mathrm{Cr}, \mathrm{Hg}$, and $\mathrm{Co}[2,3]$.

Color pollutants resulting from the fabric coloring process are discarded and flowed into the waters, which will eventually accumulate and cause damage to the aquatic environment [4]. On the other hand, the use of synthetic dyes also affects human health 
because it can cause cancer and other skin diseases [5].

White frangipani (Plumeria acuminate) and hibiscus (Hibiscus tiliaceus) plants thrive in Indonesia and both have very thick leaves (Figure 1). White frangipani plants have many benefits, it is useful as a pain relief due to cavities, treat swollen gums, and can mature ulcers [6]. Boiled water of white frangipani leaves can also be used to treat scabies, skin ailments, and the essential ingredients of making mosquito coils. On the other hand, the frothy leaves of the white frangipani are very mash used $[7,8]$. Generally, when it grows thick, it is only cut down and left or thrown away. Thus, the need for research as a breakthrough or discovery in the use of frangipani plant leaves.

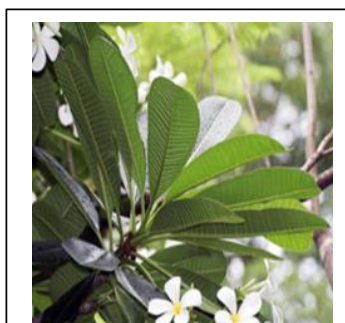

(A)

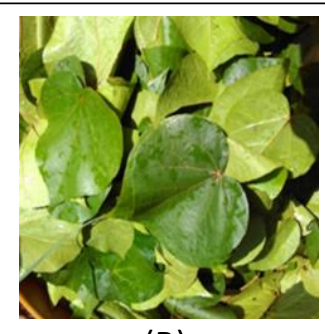

(B)
Figure 1. (A) White frangipani leaves and (B) Hibiscus leaves.

Hibiscus (Hibiscus tiliaceus) plants have also many benefits. From Leaves, buds, skin, wood, flowers, and sap have been used as traditional medicine. In Indonesia, the hibiscus leaves were used to cool the fever, eliminate phlegm, soothe the cough, and swallow for a dry throat. From phytochemical group, screening were identified that the ethanol extract of hibiscus leaves contains compounds that caused it can be used as cytotoxic, antibacterial, analgesic, and neuropharmacological agents. The hibiscus leaves the majority contains tannin compounds. Tannin is a water-soluble natural pigment that is naturally present in various types of plants. Tannin, which is a natural coloring pigment in the form of a brown coloring agent has a bitter and chelate flavor, which reacts with and agglomerates protein or various other organic compounds including amino acids and alkaloids $[9,10,11]$.

The many types of natural coloring plants that have the potential as raw materials for making natural dyes need to be examined. Abundant availability, easily renewable, cheap, and easy to use is a thought to utilize natural dye plants as textile dyes that are not only in demand by local textile industry/craftsmen but also those throughout Indonesia. White frangipani and hibiscus leaves are very abundant in Indonesia. One of the breakthroughs for them when both can be used as a natural textile dye $[12,13,14]$.

Some natural coloring pigments that are abundant around us include chlorophyll, carotenoids, tannins, and anthocyanins [15]. White frangipani leaves also contain tannins beside alkaloids and cyanogenic glycosides. The tannin content in white frangipani and hibiscus leaves is between $4-10 \%$ and this has the potential to make it as a coloring agent. Tannin is one of the natural coloring pigments which will give a brown color $[7,10]$.

The ease of tannins dissolving in water and the abundance of white frangipani and hibiscus leaves gives the idea to use both leaves as coloring agents. Until now, research about the use of white frangipani leaves and hibiscus as a textile natural dye 
has not been reported yet. The potential of tannins to produce a brown color on the fabric can provide benefits to batik artisans who mostly use color brown. Based on the description, it can be assumed that the leaves of white frangipani and hibiscus plants can be used as a source of natural textile dyes, especially color brown.

\section{METHODS}

\section{Tools and Materials}

Tools: scissors, blender, dryer, water heater, measuring and beaker glass, sifter 150 mesh, vaporizer cup, pounder and porcelain cup, balance, ironing, spatula, oven, fan, stirrer, clamp, Launder meter, Crock meter, GrayScale Standard, and Standard Staining Scale.

Materials: Hibiscus (Hibiscus tiliaceus) leaves, white frangipani (Plumeria acuminate) leaves, white (Japanese) cotton fabric, white polyester fabric, distilled water, $\mathrm{Na}_{2} \mathrm{CO}_{3}$, $\mathrm{Al}_{2}\left(\mathrm{SO}_{4}\right)_{3}, \mathrm{FeSO}_{4} .7 \mathrm{H}_{2} \mathrm{O}, \mathrm{CaCO}_{3}$, and teepol.

\section{Preparation of Natural Dyes}

Leaves as a source of coloring should be washed using water and served cleanly. Leaves are cut until smooth to make the drying process easier, drying is done by sunlight. Furthermore, leaves are mashed by grinding using a blender to produce leaves powder (simplicia). The simplicial is extracted by boiling of 250 grams of simplicia using $2.5 \mathrm{~L}$ water for about 2 hours or until the remaining water volume is one third. During the boiling process, the leave powder should be stirred regularly. Next, the extraction is cooled and filtered using a 150 mesh of a sieve. The resulting filtrate is reheated for the concentration process to become a paste. Then the paste is dried and mashed into a fine dye powder.

\section{Staining Process}

\section{a. Mordanting}

Four pieces of cotton and polyester cloth measuring $20 \times 30 \mathrm{~cm}$ are processed for the mordanting by mixing 20 grams of $\mathrm{Al}_{2}\left(\mathrm{SO}_{4}\right)_{3}$ and 1.2 grams of $\mathrm{Na}_{2} \mathrm{CO}_{3}$ into $2 \mathrm{~L}$ water. The mixture is boiled, added the cloth, and stirred for 1 hour. Then the heat is turned off and the fabric is soaked overnight (24 hours), after that, it is rinsed, dried, and ironed.

\section{b. Fabric Staining}

The fabric then enters the coloring stage. The dye is mixed into distilled water in a ratio of 1:50 (w/v), stirred until dissolved, and boiled. The fabric to be colored is added into the mixture, boiled for 30 minutes by turning back and forth until the color is evenly distributed.

\section{c. Color Locking (Fixation)}

Fixers used in this study were $\mathrm{Al}_{2}\left(\mathrm{SO}_{4}\right)_{3}$ (alum) solution, $\mathrm{FeSO}_{4} .7 \mathrm{H}_{2} \mathrm{O}$, and $\mathrm{CaCO}_{3}$ (calcium oxide). How to make a fixer solution is to weigh alum, ferrous sulfate, and calcium oxide as much as 70 grams each and dissolve it in $1 \mathrm{~L}$ of distilled water, stir until dissolved. The mixture is allowed precipitate, then the bright/clear solution is decanted and used for fixation. The locking process is carried out by inserting the colored cloth into it and soaking it for about 30 minutes. Then the fabric is lifted, dried, and washed with soap until clean. Next, the fabric is aired and ironed [16]. 


\section{Quality testing of dyes}

Testing the quality of water extracts of frangipani and hibiscus leaves-powder as a textile natural dye was carried out in the laboratory of Akademi Tekstil Warga (ATW) Surakarta. Tests for colorfastness against washing were performed according to SNI ISO 105-C06:2010 [17] and colorfastness against rubbing according to SNI ISO 105X12:2012 [18].

\section{a. Washing Test}

The colorfastness against washing was performed by washing dyed cloth coated with two strands of white fabric sewn on both edges. The washing uses a device called a launder meter. Assessment of colorfastness in textiles was carried out by observing the first color changes of the test sample with an indication of not changing, there is a little change and changed. Visual assessment is to compare the color changes that occur on the fabric samples with a standard color change. Known standards are standards issued by the International Standards Organization and American Association of Textile Chemists and Colorists (ISO/AATCC), which is the Gray Scale standard and the Staining Scale standard. Colorimetric Specification of Grayscale and Staining scale uses Adam's Chromatic Value in Color Difference.

\section{b. Rubbing test}

The working principle to test the color fastness against rubbing is by rubbing cloth that has undergone a coloring process, in wet and dry conditions. Wet cloth or dry cloth is installed in the sample area on the crock meter. After the rubbing process, the fabric is evaluated using a staining scale.

\section{RESULTS AND DISCUSSION}

The yields of water extracts of white frangipani and (Plumeria acuminate) and hibiscus (Hibiscus tiliaceus) leaves powders were $27 \%$ and $11 \%$, respectively. Both leaves extracts obtained have the same dark brown color (Fig. 1b and 1d). As described above that tannin is one of the natural coloring pigments which will give a brown color [7,10]. It showed that the chemical component extracted by water from both leaves is tannin. The resulting extracts will be used as fabric dyes; the fabrics used are cotton and polyester.

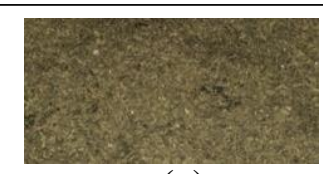

(a)

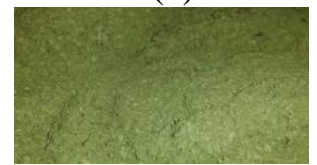

(c)

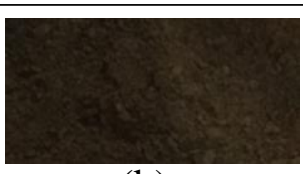

(b)

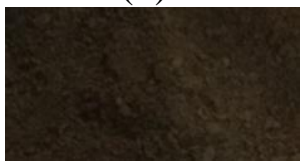

(d)
Figure 1. Simplicia (a) and dye powder (b) of white frangipani leaves. Simplicia (c) and dye powder (d) of hibiscus leaves.

Cotton fabric gives the best results due to the cellulose content, which reaches $94 \%$. Cellulose fibers have very hygroscopic properties so that the tannin color pigments which are soluble in water can be absorbed well. Polyester is hydrophobic because of the hydrogen bond between $-\mathrm{OH}$ and $-\mathrm{COOH}$ in the molecule. Therefore, polyester fibers are difficult to approach by water or dyes dissolved in water. In immersing hydrophobic fibers such as polyester, the structure of the tissues is so compact that water is difficult to penetrate. 
Thus, the diffusion of dyes with the help of water is difficult. This low diffusion causes low fabric absorption. Dyes are only able to stain polyester fabric but do not color [19].

\section{Color Staining Test}

Cotton and polyester are test fabrics in which they can be used to bind several types of dyes. Cotton represents a type of natural structure derived from natural materials, and polyester is a material formed from chemical processes [19]. Both have their respective advantages; here will not discuss the benefits but will focus on how the dye can be bound to the fabric. There are a series of tests conducted, tests that underlie the strength of the color, and there the washing test is used to find out how the dye can be resistant to washing. Staining scale testing aims to determine the fastness to laundry by looking at the stains flanking the sample during the washing process. Table 1 will explain how dyes are tested in the washing process.

Table 1. Color staining of basic washing of Hibiscus and Frangipani Leaves

\begin{tabular}{|c|c|c|c|c|c|c|c|}
\hline \multirow{2}{*}{$\begin{array}{l}\text { Type of } \\
\text { Fabric }\end{array}$} & \multirow{2}{*}{ Fixer Type } & \multicolumn{3}{|c|}{ Frangipani Leaf } & \multicolumn{3}{|c|}{ Hibiscus Leaf } \\
\hline & & SS & $C D$ & Evaluation & SS & $C D$ & Evaluasi \\
\hline \multirow[t]{3}{*}{ Cotton } & $\begin{array}{l}\mathrm{Al}_{2}\left(\mathrm{SO}_{4}\right)_{3} \\
\text { alum }\end{array}$ & $3-4$ & 5,6 & pretty good & 3 & 5,6 & pretty good \\
\hline & $\begin{array}{c}\mathrm{CaCO}_{3} \\
\text { calcium oxide }\end{array}$ & $3-4$ & 5,6 & pretty good & 4 & 4,5 & pretty good \\
\hline & $\begin{array}{l}\mathrm{FeSO}_{4.7 \mathrm{H}_{2} \mathrm{O}} \\
\text { ferrous sulfate }\end{array}$ & $3-4$ & 5,6 & pretty good & $3-4$ & 5,07 & pretty good \\
\hline \multirow[t]{3}{*}{ polyester } & $\begin{array}{l}\mathrm{Al}_{2}\left(\mathrm{SO}_{4}\right)_{3} \\
\text { alum }\end{array}$ & 4 & 4 & good & $3-4$ & 6,4 & pretty good \\
\hline & $\begin{array}{c}\mathrm{CaCO}_{3} \\
\text { calcium oxide }\end{array}$ & $3-4$ & 5,6 & pretty good & $3-4$ & 5,6 & pretty good \\
\hline & $\begin{array}{c}\mathrm{FeSO}_{4.7 \mathrm{H}_{2} \mathrm{O}} \\
\text { ferrous sulfate }\end{array}$ & 4 & 4 & good & $3-4$ & 5,6 & pretty good \\
\hline
\end{tabular}

$\mathrm{CD}=$ Color difference $; \mathrm{SS}=$ Staining Scale

The fabric has been washed with a laundry meter and dried, the quality of the dye is determined from the scale of the color change (Gray Scale) and staining color on a white cloth (Staining scale). Staining Scale (SS) and Color Difference (CD) describe how the dye will work on the fabric fibers and stick. The Washing test showed no significant difference between hibiscus and frangipani leaves in providing color resistance when washing. The dye is firmly attached to the fabric with quite good quality. Frangipani and Hibiscus leaves extract together work quite well for the washing test. Tannins are polyphenol compounds which have large molecular weights consisting of hydroxy and carboxyl groups. In the coloring process, the cloth that has cellulose fibers, such as cotton, when immersed in water will swell and the pores of the fiber will open. If the cloth is soaked together with coloring powder that contains tannins, tannins can then enter the fiber and will be bound by the reactive groups in the cellulose fiber so tannins are difficult to get out of the fiber again [20].

Complex compounds have stability, which is influenced by several reasons, including ligands, central atomic ionic potential, and bond strength. Ligand means the dye found in extracts of frangipani and hibiscus 
leaves powder. Thus, the stability of complex compounds is only influenced by the central ionic potential and bond strength. The smaller the radius and the higher the charge of metal ions, the ionic potential of the atomic and the bond strength between the metal ion and the dye is more significant and the more stable the complex compounds formed [21].

Fixer ferrous sulfate becomes dark green (army green) on cotton and gray on polyester. This fixer becomes a dark color because of the covalent bonding of tannin coordination with the $\mathrm{Fe}^{2+}$ metal ion produces a black salt Ferro tannate complex. This fixation makes the bonding strength of the dye very strong. It can withstand the color on the fabric, especially in the polyester complex Ferro tannate occurs strongly on the fabric and is not easily separated despite washing [22].

\section{Gray Scale Test}

Gray Scale Testing seeks to determine the fastness to laundry by looking at the differences of after washing and before washing. The smaller the color difference value means the better the fastness value. This can be seen also from the value on the increased gray scale which means better fastness.

Table 2. Color Change (Gray Scale) of Hibiscus and Frangipani Leaves

\begin{tabular}{|c|c|c|c|c|c|c|c|}
\hline \multirow{2}{*}{$\begin{array}{l}\text { Type of } \\
\text { Fabric }\end{array}$} & \multirow{2}{*}{ Fixer Type } & \multicolumn{3}{|c|}{ Frangipani Leaf } & \multicolumn{3}{|c|}{ Hibiscus Leaf } \\
\hline & & GS & $C D$ & Evaluation & GS & $C D$ & Evaluation \\
\hline \multirow[t]{3}{*}{ Cotton } & $\begin{array}{l}\mathrm{Al}_{2}\left(\mathrm{SO}_{4}\right)_{3} \\
\text { alum }\end{array}$ & $2-3$ & 5,4 & less & 3 & 3,4 & less \\
\hline & $\begin{array}{c}\mathrm{CaCO}_{3} \\
\text { calcium oxide }\end{array}$ & 2 & 6,8 & less & $2-3$ & 4,8 & less \\
\hline & $\begin{array}{l}\mathrm{FeSO}_{4} \cdot \mathrm{H}_{2} \mathrm{O} \\
\text { ferrous sulfate }\end{array}$ & 2 & 6 & less & 2 & 5,4 & less \\
\hline \multirow[t]{3}{*}{ polyester } & $\begin{array}{l}\mathrm{Al}_{2}\left(\mathrm{SO}_{4}\right)_{3} \\
\text { alum }\end{array}$ & $2-3$ & 4,2 & less & 2 & 6,8 & less \\
\hline & $\begin{array}{c}\mathrm{CaCO}_{3} \\
\text { calcium oxide }\end{array}$ & $1-2$ & 8,5 & bad & 2 & 6 & less \\
\hline & $\begin{array}{l}\mathrm{FeSO}_{4} \cdot \mathrm{H}_{2} \mathrm{O} \\
\text { ferrous sulfate }\end{array}$ & $2-3$ & 4,8 & less & $2-3$ & 4 & less \\
\hline
\end{tabular}

$\mathrm{CD}=$ Color difference; GS = Gray scale

Hibiscus and frangipani leaves have the same grayscale in both cotton and polyester (Table 2). Grayscale test results give a sign that both have the same effect in terms of resistance in washing, especially the color changes that occur after the washing process. Both dyes produce qualities that are lacking in grayscale values. Polyester with a calcium oxide fixer on frangipani leaves gives poor results; this has a difference from all test results. Several things need to be looked at again for reasons why this happened.
A straightforward explanation is that the $\mathrm{Ca}^{2+}$ from the lime solution causes the bond between the ions and the dyes in the fabric fibers to bind to other fabric fibers so that the dye molecules fixed in the fiber become more muscular and not easily come out [23]. Fixer that can lock dyes properly is an alum fixer. Colorfastness is related to the stability of complex compounds that are formed during the fixation process. The fastness with alum fixer gives the best value means that the dye complex with alum forms 
a stronger bond than the bond between the dye complex with calcium oxide. The presence of fading is related to the strength of the bond between the fabric fibers and the coloring agent [24].

Smaller fastness values indicate low quality of color resistance to washing. That value can occur because of the nature of calcium oxide, which is unable to open the pores of polyester fabric. Moreover, the texture of polyester is denser than cotton fabrics. So that the pores do not open optimally despite the addition of fixer. When the thick pores are already in the dye particles, the more concentrated the extract solution, the dye particles will tend to stick to the surface of the fabric. Then when washed the dye particles that stick to it will easily be separated from the fabric that makes a lot of fades [24].

\section{Rubbing test}

Rubbing test to determine the fastness against rubbing by looking at stains on fabric that has rubbed in dry or wet conditions compared with the original cloth that does not smear. The way it works is by looking at and comparing the stained tissue stained with the type of fabric that is not tainted in terms of change and color contrast by referring to the list of blast-resistant fastness values. The rubbing is carried out in wet and dry conditions is intended to see the difference in bond strength between the dye and fabric fibers in both conditions when rubbed. In general, in wet conditions, the pores of the fabric open, so that when given a movement with heat, the dye that is not strongly bound can easily get out of the hole of the fabric fiber and cause a decrease in the colorfastness value.

Table 3. Rubbing test of Hibiscus and Frangipani Leaves

\begin{tabular}{|c|c|c|c|c|c|c|c|c|}
\hline \multirow{2}{*}{$\begin{array}{l}\text { Type of } \\
\text { Fabric }\end{array}$} & \multirow{2}{*}{ Fixer Type } & \multirow{2}{*}{$\begin{array}{l}\text { Rubbing } \\
\text { Type }\end{array}$} & \multicolumn{3}{|c|}{ Frangipani Leaf } & \multicolumn{3}{|c|}{ Hibiscus Leaf } \\
\hline & & & SS & $C D$ & Evaluation & SS & $C D$ & Evaluation \\
\hline \multirow[t]{6}{*}{ Cotton } & \multirow{2}{*}{$\begin{array}{l}\mathrm{Al}_{2}\left(\mathrm{SO}_{4}\right)_{3} \\
\text { alum }\end{array}$} & Dry & 4 & 3,9 & Good & $2-3$ & 10,9 & less \\
\hline & & Wet & 4 & 6,6 & pretty good & 3 & 9,1 & enough \\
\hline & \multirow{2}{*}{$\begin{array}{c}\mathrm{CaCO}_{3} \\
\text { calcium oxide }\end{array}$} & Dry & 3 & 8 & enough & $3-4$ & 10,9 & less \\
\hline & & Wet & 3 & 8 & enough & $2-3$ & 10,2 & less \\
\hline & \multirow{2}{*}{$\begin{array}{l}\mathrm{FeSO}_{4} .7 \mathrm{H}_{2} \mathrm{O} \\
\text { ferrous sulfate }\end{array}$} & Dry & 4 & 4 & good & $2-3$ & 10,2 & less \\
\hline & & Wet & 2 & 16 & less & 2 & 14,4 & less \\
\hline \multirow[t]{6}{*}{ Polyester } & \multirow{2}{*}{$\begin{array}{l}\mathrm{Al}_{2}\left(\mathrm{SO}_{4}\right)_{3} \\
\text { alum }\end{array}$} & Dry & $3-4$ & 6,4 & pretty good & $2-3$ & 12,1 & less \\
\hline & & Wet & 3 & 8 & Enough & $2-3$ & 11,3 & less \\
\hline & \multirow{2}{*}{$\begin{array}{c}\mathrm{CaCO}_{3} \\
\text { calcium oxide }\end{array}$} & Dry & $3-4$ & 6,4 & pretty good & 3 & 7,5 & enough \\
\hline & & Wet & $3-4$ & 6,4 & enough & 3 & 8,3 & enough \\
\hline & \multirow{2}{*}{$\begin{array}{l}\mathrm{FeSO}_{4} .7 \mathrm{H}_{2} \mathrm{O} \\
\text { ferrous sulfate }\end{array}$} & Dry & 3 & 7,2 & enough & $2-3$ & 10,2 & less \\
\hline & & Wet & 3 & 8,3 & enough & 3 & 8 & enough \\
\hline
\end{tabular}

$\mathrm{CD}=$ Color difference; $\mathrm{SS}$ = Staining Scale

Frangipani leaves have a better quality in the rub test (Table 3 ), although divided into two, rubbing in a dry and wet state, it appears that frangipani leaves show better results than Hibiscus leaves. Rub test on the dry state of cotton gives frangipani leaves have more useful results than Hibiscus leaves, standing scale value is between 3-4 while color difference 4 shows good rubbing results. In wet state cotton for 
frangipani, leaf coloring shows better results even though the results are no better than a dry state. This result is feasible because water releases the dye when rubbed, but the color can still maintain it. Better results are shown from frangipani leaves than Hibiscus, which makes an indication that frangipani leaves are better in terms of resistance to rubbing. While looking at the quality of the rub based on the fixer, ferrous sulfate obtained the worst results with poor quality on cotton, and polyester showed the best results.

Polyester is from synthesis and not derived from nature, of course, has different structures, which make it difficult for dyes to enter the pores of the fabric. Frangipani leaves still show better results for rubbing test both dry and wet with a vulnerable value of staining scale 3-4 with color difference 6-8 while for Hibiscus leaves 2-3 with color difference 6-12. These results further indicate that frangipani will be stable in a state of rubbing and better in color quality. The quality of the fixer that is resistant to the best rub test is alum, and the least good is ferrous sulfate. The same result for cotton and polyester fabrics in both wet and dry conditions [24].

The value of fastness in cotton fabrics is better than in polyester fabrics because polyester fabrics are not natural fiber fabrics but synthetic fibers. Hence, dyes only stain the fabric instead of coloring it. The causes when given a mechanical movement in the form of white cloth rubbing on Crock meter quickly stained. Mechanical movements do the testing of textile materials, the dyes in the fabric will not fade if the bond between the dye and the fiber is strong, the color loss is due to the effect of the resulting rubbing. That is, the color fastness of leaching affects the strength of the bonds that occur between fibers, dyes, and fixers. Thus, the bond between alum fixer with cotton cloth fibers and dyes is more reliable than other fixers rubbing in a wet state does not provide a maximum value compared to rubbing in a dry state; wet rubbing shows less than the maximum amount. Due to the wet state, the fabric pores open, so that when given a movement, the dye can quickly come out of the mouth of the fabric fibers [25].

The bond strength of the dyes-fiberalum complex is more durable, and the complex compounds produced are more stable and more challenging to decompose so that its fastness is better. In the calcium oxide fixer dyes are not able to enter the fibers maximally due to the breaking of the bond between the fabric fibers and the dyes so that the absorbency of the fabric fibers is lost and causes the remaining dyes to stick to the surface of the fabric fibers naturally [26].

\section{CONCLUSION}

The results of this research have proven that the leave powder of hibiscus (Hibiscus tiliaceus) and white frangipani (Plumeria acuminate) which have been extracted with boiling water gave yields of $11 \%$ and $27 \%$, respectively. Based on an assessment of colorfastness against washing and rubbing, it revealed that water extract powder from white frangipani leaves has the potential to become a natural textile dye compared to hibiscus leaves. However, due to their GS value is still lacking, they still need to find conditions to increase the value. These efforts can be performed through optimizing 
the use of fixers, the time of coloring, and the concentration of dyes used.

\section{REFERENCES}

[1] H. Rymbai, R. R. Sharma, \& M. Srivasta, "Bio-colorants and Its Implications in Health and Food Industry-A Review." International Journal of Pharmacological Research, vol. 3, pp. 2228-2244, 2011.

[2] A. Ajmal, I. Majeed, R. N. Malik, M. Iqbal, M. A. Nadeem, I. Hussain, S. Yousaf, G. Mustafa, M. I. Zafar, \& M. A. Nadeem, "Photocatalytic degradation of textile dyes on Cu2O-CuO/TiO2 anatase powders. Journal of environmental chemical engineering, vol. 4, no. 2, pp. 2138-2146, 2016.

DOI:10.1016/j.jece.2016. 03.041

[3] G. M. Ratnamala, K. V. Shetty, \& G. Srinikethan, "Removal of remazol brilliant blue dye from dye-contaminated water by adsorption using red mud: equilibrium, kinetic, and thermodynamic studies". Water, Air, \& Soil Pollution, vol. 223, no. 9, pp. 6187-6199, 2012.

DOI:10.1007/s11270-012-1349-4

[4] B. Baliarsingh, A. K. Panda, J. Jen, T. Das, \& N. B. Das, "Exploring sustainable technique on natural dye extraction from native plants for textile: identification of colourants, colourimetric analysis of dyed yarns and their antimicrobial evaluation. Journal of Cleaner Production, vol. 37, pp. 257-264, 2012.

DOI:10.1016/j.jclepro.2012.07.022

[5] E. L. Septiani, O. P. Prastuti, Y. Kurniati, M. A. Fauziyah, H. Setyawan, H. Kanda, \& M. Goto, Sorption Efficiency in Dye Removal and Thermal Stability of Sorghum Stem Aerogel. In Materials Science Forum (Vol. 966, pp. 175-180, 2019). Trans Tech Publications Ltd. DOI:10.4028/www.scientific.net/MSF. 966.175
[6] N. Hidajati, \& Q. Qodriyah. "Toxicity Test Toward Dichloromethane Fraction from White Frangipani Leaves (Plumeria alba)." Seminar Nasional KimiaNational Seminar on Chemistry (SNK 2018). Atlantis Press, 2018.

DOI:10.2991/snk-18.2018.13

[7] R. T. Wahyudi, "Pengaruh Ekstrak Etil Asetat Getah Kamboja (plumeria acumenate. Wt ait) Terhadap Pertumbuhan dan Daya Hambat Bakteri Staphylococus Aureus." STIGMA: Jurnal Matematika dan IImu Pengetahuan Alam Unipa 6.02, 2013.

DOI: 10.36456/stigma.vol6.no02.a525

[8] Y. Liu, H. Wang, S. Wei, \& Z. Yan, "Chemical composition and antimicrobial activity of the essential oils extracted by microwave-assisted hydrodistillation from the flowers of two Plumeria species. Analytical letters, vol. 45, no. 16, pp. 2389-2397, 2012.

DOI:10.1080/00032719.2012.689905

[9] K. S. Narender, D. Kumar, \& V. Kumar, "Antinociceptive and anti-inflammatory activity of Hibiscus tiliaceus leaves." International Journal of Pharmacognosy and Phytochemical Research, vol. 1, no. 1, 2009.

DOI:10.1080/00032719.2012.689905

[10] L. Istiqomah, H. Hardian, A. Febrisantosa, \& D. Putra, "Waru leaf (Hibiscus tiliaceus) as saponin source on in vitro ruminal fermentation characteristic. Journal of the Indonesian Tropical Animal Agriculture, vol. 36, no. 1, pp. 43-49, 2011. DOI:10.14710/jitaa.36.1.43-49

[11] S. M. Abdul-Awal, S. Nazmir, S. Nasrin, T. R. Nurunnabi, \& S. J. Uddin, "Evaluation of pharmacological activity of Hibiscus tiliaceus." Springer Plus, vol. 5, no. 1, p.1209, 2016. DOI:10.1186/s40064-016-2891-0 
[12] T. Bechtold, R. Mussak, A. Mahmud-Ali, E. Ganglberger, \& S. Geissler, "Extraction of natural dyes for textile dyeing from coloured plant wastes released from the food and beverage industry." Journal of the Science of Food and Agriculture, vol. 86, no. 2, pp. 233-242, 2006.

DOI:10.1002/jsfa.2360

[13] S. Baliarsingh, J. Jena, T. Das, N. B. Das, "Role of cationic and anionic surfactants in textile dyeing with natural dyes extracted from waste plant materials and their potential antimicrobial properties." Industrial Crops and Products, 50, pp.618-624, 2013. DOI:10.1016/.jindcrop.2013.08.037

[14] Sanghi, Rashmi, B. Bhattacharya, A. Dixit, \& V. Singh. "Ipomoea dasysperma seed gum: An effective natural coagulant for the decolorization of textile dye solutions." Journal of environmental management, vol. 81, no. 1, pp. 36-41, 2006.

DOI:10.1016/.jenvman.2005.09.015

[15] A. K. Guha, "A Review on Sources and Application of Natural Dyes in Textiles." International Journal of Textile Science, vol. 8, no. 2, pp. 38-40, 2019.

DOI:10.5923/j.textile.20190802.02

[16] S. S. Sangita \& P. Satsangi. "Sesbania Aculeata: A Plant for Colouring Cotton and Silk." International Journal of Emerging Technology and Advanced Engineering. vol 4, no. 10, pp. 141-145, 2014.

[17] SNI ISO 105-C06, Tekstil-Cara uji tahan luntur warna - Bagian C06: Tahan luntur warna terhadap pencucian rumah tangga dan komersial, 2010.

http://sispk.bsn.go.id/SNI/DetailSNI/10809

[18] SNI ISO 105-X12, Tekstil-Cara uji tahan luntur - Bagian X12: Tahan luntur warna terhadap gosokan, 2012.

http://sispk.bsn.go.id/SNI/DetailSNI/10809

[19] S. Bahri, Jalaluddin, Rosnita, "Pembuatan Zat Warna Alami dari Kulit Batang Jamblang (Syzygium cumini) sebagai Bahan Dasar Pewarna Tekstil."
Jurnal Teknologi Kimia Unimal, vol. 6, no. 1, pp. 10-19, 2017.

DOI:10.29103/jtku.v6i1.465

[20] L. Ammayappan \& M. J. Jeyakod, "An overview on application of tanning in textile processing." Man-Made Textiles in India. vol. 50, no. 8, pp. 293-297, 2007.

[21] Paryanto, A. Purwanto, E. Kwartiningsih, \& E. Mastuti, "Pembuatan Zat warna Alami dalam Bentuk Serbuk untuk Mendukung Industri Batik di Indonesia." Jurnal Rekayasa Proses, vol. 6, no. 1, pp. 26-29, 2012.

DOI:10.22146/jrekpros.2454

[22] M. Manurung, "Aplikasi Kulit Buah Manggis (Garcinia mangostana L.) sebagai Pewarna Alami pada Kain Katun secara Pre-mordanting." Jurnal Kimia, vol. 6, no. 2, pp. 183-190, 2012.

[23] P. A. Handayani \& A. A. Mualimin, "Pewarna Alami Batik Dari Tanaman Nila (Indigofera) dengan Katalis Asam." Jurnal Bahan Alam Terbuka. vol. 2, no. 1, pp. 1-6, 2013.

DOI: 10.15294/jbat.v2i1.2909

[24] K. H. Prabhu \& M. D. Teli, "Eco-dyeing using Tamarindus indica $L$. seed coat tannin as a natural mordant for textiles with antibacterial activity." Journal of Saudi Chemi cal Society, vol. 18, no. 6, pp. 864-872, 2014.

DOI:10.1016/j.jscs.2011.10.014

[25] M. Thomas, M. Manurung, \& I. A. R. A Asih, "Pemanfaatan Zat Warna Alam Dari Ekstrak Kulit Akar Mengkudu (Morinda citrifolia Linn) Pada Kain Katun. Journal Of Chemistry, vol. 7, no. 2, pp. 119-126, 2013. DOI:10.24843/JCHEM.2013.v07.i02.p02

[26] E. S. Ferreira, A. N. Hulme, H. McNab, $\&$ A. Quye. "The natural constituents of historical textile dyes." Chemical Society Reviews, vol. 33, no. 6, pp. 329-336, 2004. DOI:10.1039/B305697J 